ISSN 1392-3196 / e-ISSN 2335-8947

Zemdirbyste-Agriculture, vol. 103, No. 3 (2016), p. 251-258

DOI 10.13080/z-a.2016.103.032

\title{
Application of biofertilizers and zinc increases yield, nodulation and unsaturated fatty acids of soybean
}

\author{
Raouf SEYED SHARIFI \\ College of Agricultural Sciences and Natural Resources, University of Mohaghegh Ardabili \\ Daneshgah str., 56199-11367 Ardabil, Iran \\ E-mail: raouf ssharif@yahoo.com
}

\begin{abstract}
In order to study the effects of biofertilizers and zinc on yield, nodulation state and fatty acids composition of soybean, factorial experiments were conducted using a randomized complete block design with three replications during 2013 and 2014 cropping seasons. Experimental factors included nano zinc oxide in four levels: without nano zinc oxide $(\mathrm{Zn} 0)$ as control, application of $0.3(\mathrm{Zn} 1), 0.6(\mathrm{Zn} 2)$ and $0.9(\mathrm{Zn} 3) \mathrm{g} \mathrm{L}^{-1}$, and five biofertilizers levels: no biofertilizer (B0), seed inoculation by Bradyrhizobium japonicum (B1), B. japonicum + Azosprillum lipoferum strain OF (B2), B. japonicum + Pseudomonas putida strain 186 (B3) and B. japonicum + A. lipoferum strain $\mathrm{OF}+P$. putida strain 186 (B4). The results showed that maximum number of nodules per plant (16.55) and grain yield $\left(1875 \mathrm{~kg} \mathrm{ha}^{-1}\right)$ were recorded at the application of biofertilizer and nano zinc oxide as Zn3B4. The highest dry weight of nodules per plant, the number of pods and grains per plant were obtained in application of nano zinc oxide as $\mathrm{Zn} 3$ and biofertilizers as B4. Oil and protein content increased through the application of biofertilizers and nano zinc oxide. The maximum oil content was obtained by applying $0.9 \mathrm{~g} \mathrm{~L}^{-1}$ nano zinc oxide and inoculation as B4. The saturated fatty acids (palmitic and stearic acids) declined by inoculation with biofertilizer in comparison with the control, while unsaturated fatty acids (linoleic, linolenic and oleic) were increased. Results showed that both application of biofertilizer and $0.9 \mathrm{~g} \mathrm{~L}^{-1}$ nano zinc oxide (Zn3B4) increased grain yield by about $68 \%$ in comparison with $\mathrm{Zn0B0}$. Based on the results, it was concluded that co-inoculation with B. japonicum + plant growth promoting rhizobacteria and nano zinc oxide application can be recommended for profitable soybean production.
\end{abstract}

Key words: Glycine max, oil content, plant growth promoting rhizobacteria, rhizobium, yield.

\section{Introduction}

Soybean (Glycine max (L.) Merr) is one of the most important oil seed crops in the world. It contains $18 \%$ to $22 \%$ oil, highly desirable in diet and has $40 \%$ to $42 \%$ protein. It is native to parts of Asia. In warmer Mediterranean areas, like California, soybean is usually planted in the autumn. In cooler Mediterranean areas, like central Italy, it is planted in the spring (Ali, 2010). Zinc (Zn) foliar application (Heidarian et al., 2011) and seed inoculation with biofertilizers such as plant growth promoting rhizobacteria (PGPR) and Bradyrhizobium (Oscar et al., 2014), are important effective factors in increasing soybean yield and nodulation.

Legumes fix atmospheric nitrogen due to the relationship that exists between legume plants and a group of soil bacteria commonly known as rhizobacterium. This symbiotic relationship allows the bacteria to live on the roots of the legume plant, consuming carbohydrates from the plant and providing the plant with nitrogen that the bacteria convert into plant-usable form. Without these beneficial bacteria, legumes cannot fix nitrogen. In order to insure good nitrogen fixation by the legume, it is necessary to inoculate the legume with the proper strains of bacteria prior to planting the seeds. Oscar et al.
(2014) reported that the nitrogen demand of soybean can be supplied via biological nitrogen fixation through the inoculation with the selected Bradyrhizobium japonicum and PGPR. Especially, in soils where the soybean crop has not been grown previously, compatible populations of Bradyrhizobia are seldom available (Abaidoo et al., 2007).

PGPR are a group of bacteria that actively colonize plant roots and promote growth when added to seeds, roots or tubers (Wu et al., 2005). Examples from the literature have shown the capacity of some plant growth promoting rhizobacteria (PGPRs) to modify nodule formation or even biological nitrogen fixation when they are co-inoculated with rhizobacterium. Some mechanisms used by rhizobacterium to alter nodule formation or biological nitrogen fixation are the release of phytohormones such as auxins, gibberellins, cytokinins and ethylene (Bashan, deBashan, 2010), and/or systemic induction of secondary metabolites. Linu et al. (2009) reported that inoculation with phosphate solubilizing bacteria improved nodulation, root and shoot biomass of the crop. Studies carried out by Oscar et al. (2014) clearly revealed that co-inoculation of Bradyrhizobium and PGPR microorganisms significantly improved nodulation 
of soybean, and its growth and yield components as compared with the sole application of Bradyrhizobium.

$\mathrm{Zn}$ is considered as the most limiting factor in producing crops at different parts of the world. Babaeian et al. (2011) indicated that $\mathrm{Zn}$ deficiencies are common in $30 \%$ of the global soils. Soybean is sensitive to $\mathrm{Zn}$ deficiency, which is needed for chlorophyll formation, nodulation, growth hormone stimulation, lipid and protein metabolism, carbohydrate synthesis, enzymatic activity and reproductive processes (Thenua et al., 2014). It plays a vital role in photosynthesis, synthesizing RNA and DNA, synthesis of auxins, nitrogen fixation and production of biomass (Kobraee et al., 2011). Low solubility of $\mathrm{Zn}$ in soils rather than low total amount of $\mathrm{Zn}$ is the major reason for the widespread occurrence of $\mathrm{Zn}$ deficiency problem in crop plants. Recent research has shown that a small amount of nutrients, particularly $\mathrm{Zn}$ applied by foliar spraying significantly increases the yield of crops (Sarkar et al., 2007). Nano particles with small size and large surface area are expected to be an ideal material for use as a $\mathrm{Zn}$ fertilizer in plants. Currently the use of nano materials provides an important route to release trace elements gradually and in a controlled manner and has found its position and functions in agriculture (Naderi, Liu, 2012).

Soybeanoil composition determines theoilquality. Soybean oil is composed of saturated and unsaturated fatty acids. Major saturated fatty acids are palmitic and stearic, and major unsaturated fatty acids are oleic, linoleic and linolenic (Nacer Bellaloui et al., 2013). Luís et al. (2013) reported that inoculation with $\quad B$. japonicum enhances fatty acids content in soybean seeds. Moreover, several studies have shown that foliar application of $\mathrm{Zn}$ can significantly increase the quantity and quality of crop yield (Mirzapour, Khoshgoftar, 2006).

Determination of the effects of biofertilizers and $\mathrm{Zn}$ rates on the yield, nodulation, oil and protein contents of soybean is very important to maximize yield and economic profitability of soybean production in a particular environment. Moreover, it seems that there is little investigation about the combined effects of $\mathrm{Zn}$ fertilization and biofertilizer on these traits of soybean. Considering the above facts, the present study was undertaken to elucidate the effects of $\mathrm{Zn}$ rates and seed inoculation with biofertilizers on the quality and quantity of yield and nodulation of soybean.

\section{Material and methods}

Field experiments were conducted during 2013 and 2014 cropping seasons as factorial experiment using a randomized complete block design with three replications. Experimental factors included nano zinc oxide in four levels: without nano zinc oxide $(\mathrm{Zn} 0)$ as control, application of $0.3(\mathrm{Zn} 1), 0.6(\mathrm{Zn} 2)$ and $0.9(\mathrm{Zn} 3)$ $\mathrm{g} \mathrm{L}^{-1}$, and five biofertilizers levels: no biofertilizer (B0), seed inoculation with Bradyrhizobium japonicum (B1), B. japonicum + Azosprillum lipoferum strain OF (B2), Bradyrhizobium + Pseudomonas putida strain 186 (B3) and Bradyrhizobium + A. lipoferum strain $\mathrm{OF}+$ P. putida strain 186 (B4). Biofertilizers were isolated from the rhizospheres of soybean by Research Institute of Soil and Water, Tehran, Iran. The used nano zinc oxide had the average particle size less than $30 \mathrm{~nm}$ and special surface of particles was more than $30 \mathrm{~m}^{2} \mathrm{~g}^{-1}$. The area is located at $38^{\circ} 15^{\prime} \mathrm{N}$ latitude and $48^{\circ} 15^{\prime} \mathrm{E}$ longitude with an elevation of $1350 \mathrm{~m}$ above mean sea level. Climatically, the area is situated in the wet zone with moderate winter and hot summer in north-western Iran. The experiment was carried out on the soil with a texture of silty loam, Haplic Cambisol according to World Reference Base (WRB, 2014), with $\mathrm{pH}$ about 8.24, total organic $\mathrm{C}-5.27$ $\mathrm{g} \mathrm{kg}^{-1}$ soil, $\mathrm{Zn}-32 \mathrm{mg} \mathrm{kg}^{-1}$ and electrical conductivity (EC) about $2.3 \mathrm{ds} \mathrm{m}^{-1}$. All phosphorous $\left(75 \mathrm{~kg} \mathrm{ha}^{-1}\right.$ in the form of super phosphate) and potassium ( $75 \mathrm{~kg} \mathrm{ha}^{-1}$ in the form of potassium sulphate) fertilizers were applied as basal dose at the time of seedbed preparation. Mean temperature and precipitation during 2013 and 2014 are presented in Figure.

Irrigation, weeding and all other agronomic practices except those under study were kept normal and uniform for all treatments. Equal amount of nitrogen fertilizer as starter $\left(30 \mathrm{~kg} \mathrm{ha}^{-1}\right)$ was broadcast by hand at planting. In each plot there were 5 rows $4 \mathrm{~m}$ in length. The plots and blocks were separated by $1 \mathrm{~m}$ unplanted distances. Seed placement was done by hand in individual hills at inter-row and intra-row spacing of $60 \times 4.8 \mathrm{~cm}$. The seeds of the soybean (Glycine max (L.) Merr) variety 'Telar' were planted on $13^{\text {th }}$ and $19^{\text {th }}$ of May 2013 and 2014, respectively. For inoculation, the seeds were coated with gum Arabic as an adhesive and rolled into the suspension of bacteria until uniformly coated (Seyed

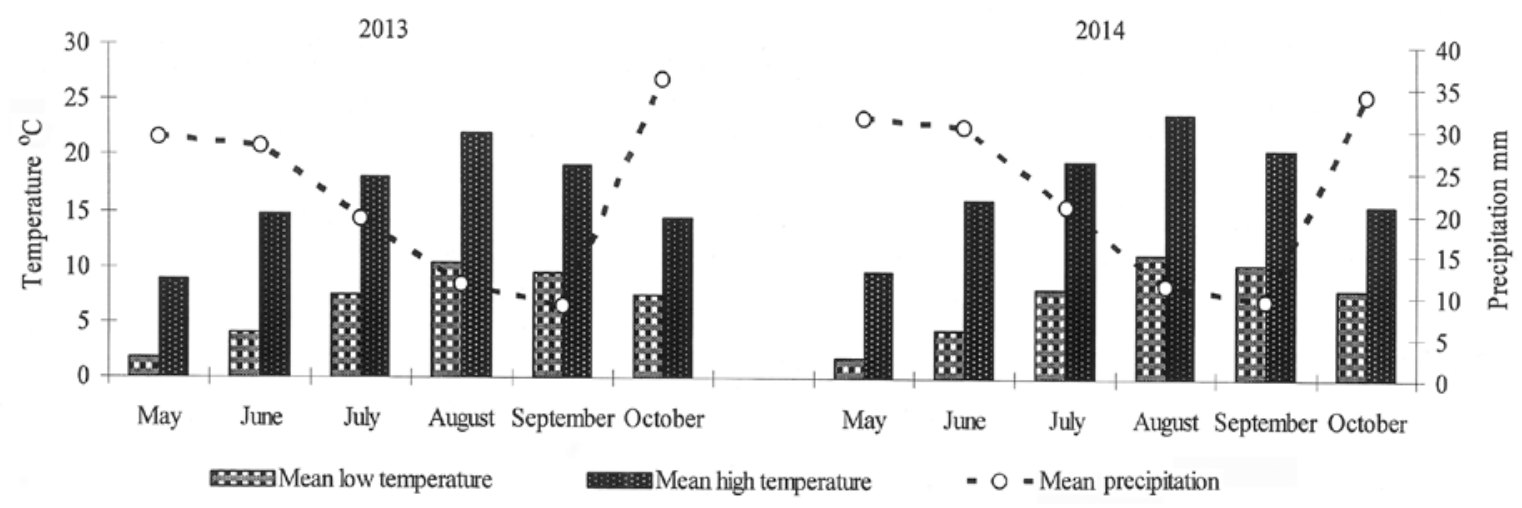

Figure. Means of minimum and maximum temperatures and rainfall recorded during 2013 and 2014 
Sharifi, Khavazi, 2011). The seeds were inoculated with Bradyrhizobium japonicum and plant growth promoting rhizobacteria (PGPR) at the rate of approximately $1 \times 10^{8}$ colony forming units (CFU) $\mathrm{mg}^{-1}$ just before planting. Two seeds were sown per hill and at the 4-5 leaf stage thinned to one plant per hill. The field was immediately irrigated after planting. In each experimental plot, two beside rows and $0.5 \mathrm{~m}$ from beginning and ending of planting lines were removed as margin and measurements were done on three rows in the middle lines. Nano zinc oxide powder was added to deionized water and placed on ultra sonic equipment (100 W and $40 \mathrm{kHz})$ on a shaker for better solution (Prasad et al., 2012). BBCH scale was used to score plant growth and development. Foliar application of nano zinc oxide was done at two growth stages - 4-6 leaf stage (BBCH 12-13) and before grain filling (BBCH 67-69). In order to study the nodules of root, four pots were sown in each plot. Each pot consisted of four plants. The pots in each plot were removed at harvest, and the soybean plants were uprooted carefully. Roots were washed using slow-running water to remove soil particles and organic debris. After washing, the number of nodules per root system was counted, and their weight was recorded after drying in an oven at $60^{\circ} \mathrm{C}$ (Namvar et al., 2011). The plants were harvested at maturity and yield components such as number of pods per plant, number of grains per pod were recorded on 8 randomly selected plants in each plot.
Seed oil and fatty acids were extracted based on AOAC (1990) protocol. Nitrogen concentration in seeds was determined by Kjeldahl analysis. The protein amount was calculated by multiplying the nitrogen concentration by 6.25 . For determination of grain yield, three central rows each $1 \mathrm{~m}$ long were harvested in each plot. The total grain weight for sampled material was recorded and converted into grain yield $\left(\mathrm{kg} \mathrm{ha}^{-1}\right)$. Analysis of variance and mean comparisons were performed using software package $S A S$. The main effects and interactions were tested using the least significant difference (LSD) test at the 0.05 probability level.

\section{Results and discussion}

As Figure shows, precipitation and temperature were generally similar in both growing seasons. Since there were not significant differences found between the two studied years, averaged data of two years were used for statistical analysis. The results indicated that $\mathrm{Zn}$ and biofertilizer had significant effects on yield quantity and quality, nodulation state and fatty acids composition of soybean (Tables 1 and 2). Moreover, interactions between $\mathrm{Zn}$ rates $\times$ biofertilizers were significant for the number of nodules, grain yield, oil and protein content and palmitic and linolenic acid amounts.

Number of nodules and weight of nodules per plant. Number and weight of nodules per plant showed significant response to nano zinc oxide and biofertilizer

Table 1. Analysis of variance and comparison of means for the experimental factors biofertilizer and nano zinc oxide on number and weight of nodules, yield and yield components of soybean (mean of two years, 2013 and 2014)

\begin{tabular}{|c|c|c|c|c|c|c|c|}
\hline Treatment & $\begin{array}{c}\text { Weight } \\
\text { of nodules } \\
\text { mg per plant }\end{array}$ & $\begin{array}{l}\text { Number } \\
\text { of nodules } \\
\text { per plant }\end{array}$ & $\begin{array}{l}\text { Number } \\
\text { of pods } \\
\text { per plant }\end{array}$ & $\begin{array}{l}\text { Number } \\
\text { of grains } \\
\text { per pod }\end{array}$ & $\begin{array}{l}\text { Number } \\
\text { of filled } \\
\text { pods } \\
\text { per plant }\end{array}$ & $\begin{array}{l}\text { Number } \\
\text { of unfilled } \\
\text { pods } \\
\text { per plant }\end{array}$ & $\begin{array}{l}\text { Grain } \\
\text { yield } \\
\mathrm{kg} \mathrm{ha}^{-1}\end{array}$ \\
\hline \multicolumn{8}{|c|}{ Nano zinc oxide } \\
\hline $\mathrm{Zn} 0=0$ & $6.07 \mathrm{~d}$ & $9.58 \mathrm{~d}$ & $17.96 \mathrm{c}$ & $2.40 \mathrm{~d}$ & $13 d$ & $4.89 \mathrm{a}$ & $1272 \mathrm{~d}$ \\
\hline $\mathrm{Zn} 1=0.3$ & $7.93 \mathrm{c}$ & $11.13 \mathrm{c}$ & $19.23 \mathrm{bc}$ & $2.59 \mathrm{c}$ & $14.63 \mathrm{c}$ & $4.61 \mathrm{a}$ & $1382.80 \mathrm{c}$ \\
\hline $\mathrm{Zn} 2=0.6$ & $8.03 \mathrm{~b}$ & $13.72 \mathrm{~b}$ & $20.91 \mathrm{~b}$ & $2.76 \mathrm{~b}$ & $16.61 \mathrm{~b}$ & $4.10 \mathrm{~b}$ & $1536 \mathrm{~b}$ \\
\hline $\mathrm{Zn} 3=0.9$ & $9.05 \mathrm{a}$ & $15.36 \mathrm{a}$ & $23.23 \mathrm{a}$ & $3.08 \mathrm{a}$ & $19.61 \mathrm{a}$ & $3.59 \mathrm{c}$ & $1706 \mathrm{a}$ \\
\hline $\operatorname{LSD}_{0.05}$ & 0.48 & 0.68 & 2.03 & 0.07 & 1.06 & 0.38 & 15.69 \\
\hline \multicolumn{8}{|c|}{ Biofertilizers } \\
\hline $\mathrm{B} 0=$ no inoculation & $6.47 \mathrm{e}$ & $9.83 \mathrm{~d}$ & $16.30 \mathrm{~d}$ & $2.29 \mathrm{e}$ & $8.32 \mathrm{e}$ & $8.09 \mathrm{a}$ & $1282.70 \mathrm{e}$ \\
\hline $\mathrm{B} 1=$ Rhizo & $7.62 \mathrm{~d}$ & $11.63 \mathrm{c}$ & $19.27 \mathrm{c}$ & $2.52 \mathrm{~d}$ & $13.41 \mathrm{~d}$ & $5.62 \mathrm{~b}$ & $1392.20 \mathrm{~d}$ \\
\hline $\mathrm{B} 2=$ Rhizo + Azosp & $8.33 \mathrm{c}$ & $12.14 \mathrm{c}$ & $20.52 b c$ & $2.65 \mathrm{c}$ & $16.51 \mathrm{c}$ & $3.81 \mathrm{c}$ & $1493 \mathrm{c}$ \\
\hline $\mathrm{B} 3=$ Rhizo + Pseudo & $9.09 \mathrm{~b}$ & $13.36 \mathrm{~b}$ & $21.94 \mathrm{ab}$ & $2.80 \mathrm{~b}$ & $19.30 \mathrm{~b}$ & $2.65 \mathrm{~d}$ & $1559.51 \mathrm{~b}$ \\
\hline $\mathrm{B} 4=$ Rhizo + Azosp + Pseudo & $9.85 \mathrm{a}$ & $14.32 \mathrm{a}$ & $23.92 \mathrm{a}$ & $3.28 \mathrm{a}$ & $21.79 \mathrm{a}$ & $1.42 \mathrm{e}$ & $1643.22 \mathrm{a}$ \\
\hline $\mathrm{LSD}_{0.05}$ & 0.53 & 0.76 & 2.27 & 0.07 & 2.11 & 0.43 & 17.54 \\
\hline Nano zinc oxide $(\mathrm{Zn})$ & $* *$ & $* *$ & $* *$ & $*$ & $* *$ & $*$ & $*$ \\
\hline Biofertilizer (B) & $* *$ & $* *$ & $* *$ & $* *$ & $*$ & $* *$ & $* *$ \\
\hline $\mathrm{Zn} \times \mathrm{B}$ & ns & $*$ & ns & ns & ns & $\mathrm{ns}$ & $*$ \\
\hline $\mathrm{CV}(\%)$ & 11.31 & 8.60 & 10.40 & 7.52 & 12.21 & 9.80 & 10.80 \\
\hline
\end{tabular}

Note. $\mathrm{Zn} 0, \mathrm{Zn} 1, \mathrm{Zn} 2$ and $\mathrm{Zn} 3$ are without nano zinc oxide, application of $0.3,0.6$ and $0.9 \mathrm{~g} \mathrm{~L}^{-1}$, respectively; B0, B1, B2, B3 and B4 are without biofertilizers, application of Bradyrhizobium japonicum, Bradyrhizobium + Azosprillum lipoferum, B. japonicum + Pseudomonas putida and B. japonicum + A. lipoferum + P. putida; $\mathrm{ns,} *$ and $* *$ show not significant and significant differences at 0.05 and 0.01 probability level, respectively. 
Table 2. Analysis of variance and comparison of means for the experimental factors biofertilizer and nano zinc oxide on oil and protein content and fatty acids composition of soybean (mean of two years, 2013 and 2014)

\begin{tabular}{|c|c|c|c|c|c|c|c|}
\hline Treatment & $\begin{array}{l}\text { Oil } \\
\%\end{array}$ & $\begin{array}{c}\text { Protein } \\
\%\end{array}$ & $\begin{array}{c}\text { Palmitic } \\
\text { acid } \\
\% \\
\end{array}$ & $\begin{array}{c}\text { Stearic } \\
\text { acid } \\
\% \\
\end{array}$ & $\begin{array}{c}\text { Oleic } \\
\text { acid } \\
\% \\
\end{array}$ & $\begin{array}{c}\text { Linoleic } \\
\text { acid } \\
\% \\
\end{array}$ & $\begin{array}{c}\text { Linolenic } \\
\text { acid } \\
\% \\
\end{array}$ \\
\hline \multicolumn{8}{|c|}{ Nano zinc oxide } \\
\hline $\mathrm{Zn} 0=0$ & $18.46 \mathrm{c}$ & $34.18 \mathrm{c}$ & $12.40 \mathrm{a}$ & $4.37 \mathrm{a}$ & $19.27 \mathrm{~d}$ & $47.56 \mathrm{~d}$ & $5.91 \mathrm{c}$ \\
\hline $\mathrm{Zn} 1=0.3$ & $20.77 \mathrm{~b}$ & $36.98 \mathrm{~b}$ & $12.19 \mathrm{~b}$ & $4.02 \mathrm{~b}$ & $20.31 \mathrm{c}$ & $48.87 \mathrm{c}$ & $6.67 \mathrm{~b}$ \\
\hline $\mathrm{Zn} 2=0.6$ & $21.31 \mathrm{ab}$ & $37.12 b$ & $12.24 \mathrm{~b}$ & $4.02 \mathrm{~b}$ & $21.09 \mathrm{~b}$ & $49.62 \mathrm{~b}$ & $7.28 \mathrm{a}$ \\
\hline $\mathrm{Zn} 3=0.9$ & $21.57 \mathrm{a}$ & $37.60 \mathrm{a}$ & $11.27 \mathrm{c}$ & $3.25 \mathrm{c}$ & $22.88 \mathrm{a}$ & $50.34 \mathrm{a}$ & $7.25 \mathrm{a}$ \\
\hline $\operatorname{LSD}_{0.05}$ & 0.59 & 0.28 & 0.09 & 0.21 & 0.44 & 0.30 & 0.28 \\
\hline \multicolumn{8}{|c|}{ Biofertilizers } \\
\hline $\mathrm{B} 0=$ no inoculation & $20.72 \mathrm{~d}$ & $35 \mathrm{e}$ & $12.14 \mathrm{a}$ & $4.51 \mathrm{a}$ & $20.51 \mathrm{e}$ & $46.76 \mathrm{~d}$ & $6.81 \mathrm{~d}$ \\
\hline $\mathrm{B} 1=$ Rhizo & $22.27 \mathrm{c}$ & $35.73 \mathrm{~d}$ & $12.11 \mathrm{ab}$ & $4.35 \mathrm{~b}$ & $21.48 \mathrm{~d}$ & $48.11 \mathrm{c}$ & $7.47 \mathrm{c}$ \\
\hline $\mathrm{B} 2=$ Rhizo + Azosp & $22.89 \mathrm{~b}$ & $36.51 \mathrm{c}$ & $12.02 \mathrm{bc}$ & $4.22 \mathrm{c}$ & $21.66 \mathrm{c}$ & $49.89 \mathrm{~b}$ & $7.61 \mathrm{bc}$ \\
\hline $\mathrm{B} 3=$ Rhizo + Pseudo & $23.32 \mathrm{ab}$ & $37.19 \mathrm{~b}$ & $11.94 \mathrm{~cd}$ & $4.11 \mathrm{~d}$ & $22.01 \mathrm{~b}$ & $50.13 \mathrm{~b}$ & $7.8 \mathrm{ab}$ \\
\hline $\mathrm{B} 4=$ Rhizo + Azosp + Pseudo & $23.68 \mathrm{a}$ & $37.95 \mathrm{a}$ & $11.91 \mathrm{~d}$ & $3.94 \mathrm{e}$ & $22.54 \mathrm{a}$ & $50.60 \mathrm{a}$ & $7.92 \mathrm{a}$ \\
\hline $\mathrm{LSD}_{0.05}$ & 0.48 & 0.31 & 0.10 & 0.09 & 0.10 & 0.34 & 0.18 \\
\hline Nano zinc oxide $(\mathrm{Zn})$ & $*$ & $* *$ & $*$ & $* *$ & $*$ & $* *$ & $*$ \\
\hline Biofertilizer (B) & $*$ & $* *$ & $* *$ & $*$ & $* *$ & $*$ & $* *$ \\
\hline $\mathrm{Zn} \times \mathrm{B}$ & $*$ & $* *$ & $*$ & ns & ns & $* *$ & $\mathrm{~ns}$ \\
\hline CV $(\%)$ & 11.20 & 8.70 & 6.40 & 9.25 & 8.11 & 7.68 & 12.33 \\
\hline
\end{tabular}

Note. Zn0, Zn1, Zn2 and Zn3 are without nano zinc oxide, application of 0.3, 0.6 and $0.9 \mathrm{~g} \mathrm{~L}^{-1}$, respectively; B0, B1, B2, B3 and B4 are without biofertilizers, application of Bradyrhizobium japonicum, Bradyrhizobium + Azosprillum lipoferum, B. japonicum + Pseudomonas putida and B. japonicum + A. lipoferum + P. putida $; \mathrm{ns,} *$ and $* *$ show not significant and significant differences at 0.05 and 0.01 probability level, respectively.

application. Application of nano zinc oxide as $\mathrm{Zn} 3$ increased the number and weight of nodules per plant by $49 \%$ and $60.33 \%$, respectively in comparison with $\mathrm{Zn} 0$ (Table 1). It is evident from the literature that the presence of high rates of $\mathrm{Zn}$ can accelerate the nodulation and symbiotic nitrogen fixation in legumes (Awlad et al., 2003). Our study indicated that application of nano zinc oxide had positive effects on nodulation state of soybean. Moreover, inoculated plants showed more number and weight of nodules per plant than non-inoculated plants. Plants inoculated with B4 showed about 8.36, 18.24, 29.26 and $52.24 \%$ higher weight of nodules per plant and $7.18,17.95,23.12$ and $45.6 \%$ higher number of nodules per plant compared to inoculate by B3, B2, B1 and B0, respectively. Oscar et al. (2014) reported that co-inoculation of Rhizobium sp. with Azospirillum sp. increased the number, weight and nitrogenase activity of root nodules in comparison with single inoculated plants.

The highest number of nodules per plant recorded in both application of biofertilizer and $0.9 \mathrm{~g} \mathrm{~L}^{-1}$ nano zinc oxide (Zn3B4) and the lowest value of this trait observed in control (Zn0B0) (Table 3). Sarawgi and Rajput (2005) reported that soybean growth, nodulation, grain yield and $\mathrm{N}_{2}$-fixation ability are often limited by Zn deficiency. They reported that $\mathrm{Zn}$ is essential for synthesis of auxins and the increased auxins due to $\mathrm{Zn}$ might have increased the number and weight of nodules. These researchers stated that co-inoculation of Bradyrhizobium and PGPR significantly improve nodulation of soybean as compared with the sole application of Bradyrhizobium or PGPR.

Plant growth and some yield attributes. Application of high $\mathrm{Zn}$ rates $\left(0.9 \mathrm{~g} \mathrm{~L}^{-1}\right)$ increased the number of filled pods per plant, number of pods per plant and grains per pod by 50.8, 29 and $28 \%$, respectively in comparison with the control. Plants inoculated with biofertilizer showed higher number of filled pods per plant, number of pods per plant and grains per pod compared to the control plants. Application of biofertilizers as B4 increased the number of filled pods per plant about 12.9, $31.9,62.4$ and $161 \%$ compared to biofertilizer application as B3, B2, B1 and B0, respectively (Table 1). These results are in line with the findings of Son et al. (2006) who suggested co-inoculation of Bradyrhizobium and PGPR significantly improve yield and yield components of soybean as compared with the sole application of Bradyrhizobium or PGPR.

The number of unfilled pods per plant was 4.89 in the control and decreased to 3.59 in application of $0.9 \mathrm{~g} \mathrm{~L}^{-1}$ of nano zinc oxide, while the number of filled pods per plant increased through the application of zinc. Increasing number of unfilled pods per plant may be due to the less assimilation in plant for filling of whole pods in low levels of nano zinc oxide application. Biofertilizers application increased significantly the number of filled pods and decreased unfilled pods compared to the control 
Table 3. Mean comparison of interaction effect between biofertilizer and nano zinc oxide on yield, nodulation and fatty acids composition of soybean (mean of two years, 2013-2014)

\begin{tabular}{|c|c|c|c|c|c|c|}
\hline $\begin{array}{l}\text { Treatment } \\
\text { compound }\end{array}$ & $\begin{array}{l}\text { Number } \\
\text { of nodules } \\
\text { per plant }\end{array}$ & $\begin{array}{c}\text { Grain yield } \\
\mathrm{kg} \mathrm{ha}^{-1}\end{array}$ & $\begin{array}{c}\text { Oil } \\
\%\end{array}$ & $\begin{array}{c}\text { Palmitic acid } \\
\%\end{array}$ & $\begin{array}{c}\text { Linoleic acid } \\
\%\end{array}$ & $\begin{array}{l}\text { Protein } \\
\quad \%\end{array}$ \\
\hline $\mathrm{Zn} 0 \mathrm{~B} 0$ & $7.42 \pm 0.37$ & $1110 \pm 55.50$ & $19.12 \pm 0.95$ & $12.94 \pm 0.64$ & $43.2 \pm 2.16$ & $31.75 \pm 1.58$ \\
\hline $\mathrm{Zn} 0 \mathrm{~B} 1$ & $8.32 \pm 0.41$ & $1210 \pm 65.50$ & $19.93 \pm 0.99$ & $12.48 \pm 0.62$ & $44.8 \pm 2.24$ & $32.26 \pm 1.61$ \\
\hline $\mathrm{Zn0B3}$ & $10.53 \pm 0.52$ & $1350 \pm 67.51$ & $20.96 \pm 1.04$ & $12.08 \pm 0.60$ & $49.19 \pm 2.45$ & $36.68 \pm 1.83$ \\
\hline $\mathrm{Zn} 0 \mathrm{~B} 2$ & $9.9 \pm 0.49$ & $1290 \pm 64.51$ & $20.25 \pm 1.01$ & $12.48 \pm 0.62$ & $49.82 \pm 2.49$ & $33.55 \pm 1.67$ \\
\hline $\mathrm{Zn0B4}$ & $11.73 \pm 0.56$ & $1410 \pm 70.55$ & $20.53 \pm 1.02$ & $12.02 \pm 0.60$ & $49.82 \pm 2.49$ & $36.66 \pm 1.83$ \\
\hline Zn1B0 & $9.03 \pm 0.45$ & $1185 \pm 59.25$ & $20.54 \pm 1.02$ & $12.58 \pm 0.62$ & $46.68 \pm 2.33$ & $35.67 \pm 1.78$ \\
\hline Zn1B1 & $10.03 \pm 0.50$ & $1300 \pm 65$ & $20.87 \pm 1.04$ & $12.31 \pm 0.61$ & $48.25 \pm 2.41$ & $37.12 \pm 1.85$ \\
\hline Zn1B2 & $10.03 \pm 0.50$ & $1390 \pm 69.50$ & $21.32 \pm 1.06$ & $12.25 \pm 0.61$ & $49.82 \pm 2.47$ & $37.32 \pm 1.86$ \\
\hline Zn1B3 & $12.24 \pm 0.61$ & $1478 \pm 73.90$ & $21.17 \pm 1.05$ & $12.17 \pm 0.60$ & $50.13 \pm 2.50$ & $37.09 \pm 1.85$ \\
\hline Zn1B4 & $14.34 \pm 0.71$ & $1560 \pm 78$ & $21.66 \pm 1.08$ & $11.9 \pm 0.59$ & $50.44 \pm 2.52$ & $37.73 \pm 1.88$ \\
\hline $\mathrm{Zn} 2 \mathrm{~B} 0$ & $12.84 \pm 0.64$ & $1320 \pm 66$ & $20.96 \pm 1.04$ & $12.44 \pm 0.62$ & $48.25 \pm 2.41$ & $36.09 \pm 1.80$ \\
\hline $\mathrm{Zn} 2 \mathrm{~B} 1$ & $13.24 \pm 0.66$ & $1452 \pm 72.66$ & $21.7 \pm 1.08$ & $12.23 \pm 0.61$ & $49.92 \pm 2.49$ & $36.9 \pm 1.84$ \\
\hline $\mathrm{Zn} 2 \mathrm{~B} 2$ & $13.29 \pm 0.66$ & $1574 \pm 78.7$ & $22.48 \pm 1.12$ & $12.31 \pm 0.61$ & $49.82 \pm 2.49$ & $37.33 \pm 1.86$ \\
\hline Zn2B3 & $14.61 \pm 0.73$ & $1610 \pm 80.50$ & $21.47 \pm 1.07$ & $12.24 \pm 0.61$ & $50.13 \pm 2.50$ & $37.14 \pm 1.85$ \\
\hline $\mathrm{Zn} 2 \mathrm{~B} 4$ & $14.64 \pm 0.73$ & $1725 \pm 86.25$ & $22.29 \pm 1.11$ & $11.76 \pm 0.58$ & $50.44 \pm 2.52$ & $38.15 \pm 1.90$ \\
\hline $\mathrm{Zn} 3 \mathrm{~B} 0$ & $14.04 \pm 0.70$ & $1525 \pm 76.25$ & $21.44 \pm 1.07$ & $12.09 \pm 0.60$ & $48.88 \pm 2.4$ & $36.45 \pm 1.82$ \\
\hline Zn3B1 & $14.82 \pm 0.74$ & $1607 \pm 80.35$ & $22.08 \pm 1.10$ & $12.09 \pm 0.60$ & $49.5 \pm 2.47$ & $36.65 \pm 1.83$ \\
\hline Zn3B2 & $15.35 \pm 0.76$ & $1720 \pm 86$ & $22 \pm 1.11$ & $10.47 \pm 0.52$ & $49.83 \pm 2.49$ & $37.84 \pm 1.89$ \\
\hline Zn3B3 & $16.05 \pm 0.80$ & $1800 \pm 90$ & $21.62 \pm 1.08$ & $10.63 \pm 0.53$ & $51.38 \pm 2.56$ & $37.84 \pm 1.89$ \\
\hline Zn3B4 & $16.55 \pm 0.82$ & $1875 \pm 93.75$ & $22.48 \pm 1.12$ & $11.06 \pm 0.55$ & $51.7 \pm 2.58$ & $39.25 \pm 1.96$ \\
\hline $\mathrm{LSD}_{0.05}$ & 0.88 & 0.20 & 0.68 & 0.62 & 0.68 & 0.62 \\
\hline
\end{tabular}

Notes. $\mathrm{Zn} 0, \mathrm{Zn} 1, \mathrm{Zn} 2$ and $\mathrm{Zn} 3$ are without nano zinc oxide, application of $0.3,0.6$ and $0.9 \mathrm{~g} \mathrm{~L}^{-1}$, respectively; B0, B1, B2, B3 and B4 are without biofertilizers, application of Bradyrhizobium japonicum, Bradyrhizobium + Azosprillum lipoferum, B. japonicum + Pseudomonas putida and B. japonicum + A. lipoferum + P. putida. Means with similar letters in each column are not significantly different.

in each plant (Table 1). Similar results have been reported by Sarawgi and Rajput (2005).

Our results showed that biofertilizers and $\mathrm{Zn}$ application had significant effects on grain yield of soybean. The highest grain yield was obtained in application of $0.9 \mathrm{~g} \mathrm{~L}^{-1}$ nano zinc oxide due to seed coinoculation by Bradyrhizobium and PGPR which had statistically significant difference with other treatments. Comparing with the non-inoculated treatment (B0), the biofertilizer treatments B4, B3, B2 and B1 increased grain yield by $28,21.5,16.3$ and $8.5 \%$, respectively. Similar findings were also reported by Oscar et al. (2014), who stated that biofertilizer alone or in combination with synthetic fertilizers significantly increased grain yield against the control. Thenua et al. (2014) stated that higher nutrient availability and favourable soil conditions due to $\mathrm{Zn}$ usage could be a possible reason for grain yield increasing. Stimulation of different crops growth by rhizobium bacterial inoculation has also been demonstrated by other studies both in laboratory and field trials. For example, it was reported that soybean yield increased by up to $48 \%$ for inoculated compared with non-inoculated plants (Egamberdiyeva et al., 2004). It has been reported that biofertilizers not only provide zinc, but also produce a variety of growth-promoting substances like; indole acetic acid, gibberellins and vitamins B (Oscar et al., 2014). In the same line, Geeta et al. (2008) noted that $\mathrm{Zn}$ is one of the essential components of nitrogenase enzyme, which might have increased the leghaemoglobin content, number of nodules and weight of nodules per plant and grain yield.

Quality parameters. Oil content in seeds was progressively increased with increasing levels of $\mathrm{Zn}$ up to $0.9 \mathrm{~g} \mathrm{~L}^{-1}$ nano zinc oxide. Application of $0.9 \mathrm{~g} \mathrm{~L}^{-1}$ nano zinc oxide increased oil content about 16.8, 15.4 and $12.5 \%$ in comparison with $\mathrm{Zn} 0$ (control), Zn2 and $\mathrm{Zn} 1$, respectively, but no significant difference was between $\mathrm{Zn} 3$ and $\mathrm{Zn} 2$ (Table 2), while protein content increased with increasing levels of nano zinc oxide. Namvar et al. (2011) reported that seed inoculation with Rhizobium increases nodulation, nitrogen uptake and could be a possible reason for increasing of protein content and yield parameters of legume crops.

Plants inoculated with biofertilizers showed higher seed oil content compared to the control plants. Thus inoculation with B4 induced a $16.8 \%$ increase of oil content 
compared to the control (Table 2). Mean comparison showed that both inoculation and $\mathrm{Zn}$ application induced an increase of oil content. Application of biofertilizer as B4 and $0.9 \mathrm{~g} \mathrm{~L}^{-1}$ nano zinc oxide (Zn3B4) showed the highest oil content (17.5\% increase over control) and in B3, B2 and B1 (about 13, 15 and $15.4 \%$ increase over control) plants in the same nano zinc oxide level, respectively. In support to our finding, Luís et al. (2013) reported that inoculation with Bradyrhizobium japonicum enhances the organic and fatty acids content of soybean seeds.

Soybean oil is composed of saturated and unsaturated fatty acids. The fatty acid composition (saturated and unsaturated) of the oil extracted from soybean samples is shown in Table 2. Effects of nano zinc oxide rates on fatty acid composition were significant. Linoleic acid (C18:2) was the most abundant fatty acid, ranging between $47.56 \%$ and $50.34 \%$, followed by oleic acid (C18:1) and linolenic acid (C18:3), with contents of $19.27-22.88 \%$ and $3.25-4.37 \%$ in various levels of nano zinc oxide. The amount of palmitic acid (C16:0) and stearic acid (C18:1) were $11.27-12.4 \%$ and $3.25-4.37 \%$, respectively (Table 2). These ranges were similar to those reported by Yin et al. (2005) in soybean.

Results showed that application of $0.9 \mathrm{~g} \mathrm{~L}^{-1}$ nano zinc oxide increased linoleic acid content about 5, 3.1 and $1.4 \%$ compared to application of $\mathrm{Zn} 0, \mathrm{Zn} 1$ and $\mathrm{Zn} 2$, respectively. Inoculation with biofertilizers as B4 induced an $8.2 \%$ increase in linoleic acid content compared to B0 or control. Means comparison indicated that application of biofertilizers as B4 and nano zinc oxide as $\mathrm{Zn3}$ (Zn3B4) increased linoleic acid content by about $19.6 \%$ in comparison with $\mathrm{Zn0B0}$ (Table 3).

Oil fatty acid composition varies according to the environmental conditions (Roche et al., 2006). Subedi and Ma (2009) found that lack of assimilate supply could result in a dramatic decline in grain weight and its composition such as protein and oil. The saturated fatty acids (palmitic and stearic acids) declined in seed inoculation with biofertilizers than the control, while unsaturated fatty acids (linoleic, linolenic and oleic acids) increased. As shown in Table 1, inoculation with biofertilizers as B4 decreased content of palmitic acid (about 1.9\% than control) and stearic acid (about 14\% than control). Luís et al. (2013) reported that inoculation with biofertilizers enhances unsaturated fatty acids content of soybean seeds.

\section{Conclusions}

1. Application of biofertilizers and zinc plays an important role in yield quantity and quality of soybean. So, the highest weight of nodules per plant, the number of pods and grains per plant, oil content were obtained through the application of high amounts of $\mathrm{Zn}$ and coinoculation of Bradyrhizobium japonicum + plant growth promoting rhizobacteria (PGPR).

2. The saturated fatty acids (palmitic and stearic acids) declined in the seeds inoculated with biofertilizer than the control, while in unsaturated fatty acids (linoleic, linolenic and oleic) were increased.

3. It seems that application of suitable amounts of $\mathrm{Zn}$ (i.e. $0.9 \mathrm{~g} \mathrm{~L}^{-1}$ ) and co-inoculation of $B$. japonicum + PGPR can be recommended for profitable soybean production.

Received 23042016

Accepted 22062016

\section{References}

Abaidoo R. C., Keyser H. H., Singleton P. W., Dashiell K. E., Sanginga N. 2007. Population size, distribution, and symbiotic characteristics of indigenous Bradyrhizobium spp. that nodulate TGx soybean genotypes in Africa. Applied Soil Ecology, 35 (1): 57-67 http://dx.doi.org/10.1016/j.apsoil.2006.05.006

Awlad H. M., Chodhary M. A. H., Talukedar N. M. 2003. Effect of sulphur and zinc on nodulation dry matter yield and nutrient content of soybean; Pakistan Journal of Biological Sciences, 6 (5): 461-466 http://dx.doi.org/10.3923/pjbs.2003.461.466

Ali N. 2010. Soybean processing and utilization. Singh G. (ed.). The soybean botany, production and uses, p. 345-374 http://dx.doi.org/10.1079/9781845936440.0345

AOAC. 1990. Method 988.05. Helrich K. (ed.). Official methods of analysis ( $15^{\text {th }}$ ed.). The Association of Official Analytical Chemists Inc.

Babaeian M., Tavassoli A., Ghanbari A., Esmaeilian Y., Fahimifard M. 2011. Effects of foliar micronutrient application on osmotic adjustments, grain yield and yield components in sunflower (Alstar cultivar) under water stress at three stages. African Journal of Agricultural Research, 6 (5): 1204-1208

Bashan Y., deBashan L. E. 2010. How the plant growth promoting bacterium Azospirillum promotes plant growth - a critical assessment. Advances in Agronomy, 108: $77-136$ http://dx.doi.org/10.1016/S0065-2113(10)08002-8

Egamberdiyeva D., Qarshieva D., Davranov K. 2004. The use of bradyrhizobium to enhance growth and yield of soybean in calcareous soil in Uzbekistan. Journal of Plant Growth Regulation, 23: 54-57 http://dx.doi.org/10.1007/s00344-004-0069-4

Geeta G., Mudenoor M. G., Savalgi V. P. 2008. Effects of micronutrientsupplemented brady rhizobiumbiofertilizers on nudulation, dry matter production and yield of soybean (Glycine max (L.) Merrill). Legume Research, 31 (1): 20-25

Heidarian A. R., Kord H., Mostafavi Kh., Amir Parviz L., Faezeh A. M. 2011. Investigating $\mathrm{Fe}$ and $\mathrm{Zn}$ foliar application on yield and its components of soybean (Glycine max (L) Merr.) at different growth stages. Journal of Agriculture Biology and Sustainable Development, 3 (9): 189-197

Kobraee S., Shamsi K., Rasekhi B. 2011. Effect of micronutrients application on yield and yield components of soybean. Annals of Biological Research, 2 (2): 476-482

Linu M., Stephen J., Jisha M. 2009. Phosphate solubilizing Gluconacetobacter sp., Burkholderia sp. and their potential interactions with cowpea (Vigna unguiculata L. Walp). International Journal of Agricultural Research, 4: 79-87 http://dx.doi.org/10.3923/ijar.2009.79.87 
Luís R., Silva M. J., Pereira J., Encarna V., González-Andrés F., Andrade B. 2013. Inoculation with Bradyrhizobium japonicum enhances the organic and fatty acids content of soybean (Glycine max (L.) Merrill) seeds. Food Chemistry, 141: $3636-3648$

http://dx.doi.org/10.1016/j.foodchem.2013.06.045

Mirzapour M. H., Khoshgoftar A. H. 2006. Zinc application effects on yield and seed oil content of sunflower grown on a saline calcareous soil. Journal of Plant Nutrition, 29: 1719-1727 http://dx.doi.org/10.1080/01904160600897430

Nacer Bellaloui A., Mengistu O., Abdelmajid K. 2013. Effects of genetics and environment on fatty acid stability in soybean seed. Food and Nutrition Science, 4: 165-175 http://dx.doi.org/10.4236/fns.2013.49A1024

Naderi M.R., Liu A. 2012. Application of nanotechnology in agriculture and refinement of environmental pollutants. Nanotechnology Journal, 11 (1): 18-26

Namvar A., Seyed Sharifi R., Sedghi M., Asghari Zakaria R., Khandan T., Eskandarpour B. 2011. Study on the effects of organic and inorganic nitrogen fertilizer on yield, yield components, and nodulation state of chickpea (Cicer arietinum L.). Communication in Soil Science and Plant Analysis, 42: 1097-1099 http://dx.doi.org/10.1080/00103624.2011.562587

Oscar M., Analía L., Virginia L. 2014. New PGPR coinoculated with Bradyrhizobium japonicum enhances soybean nodulation. Microbiology Research, 169: 609-615

Prasad T. N., Sudhakar P., Sreenivasulu Y., Latha P., Munaswamy V., Raja Reddy K., Sreep T. S., Sajanlal P. R. 2012. Effect of nanoscale Zinc oxide particles on the germination, growth and yield of peanut. Journal of Plant Nutrition, 35: 905-927 http://dx.doi.org/10.1080/01904167.2012.663443

Roche J., Bouniols A., Mouloungui Z., Barranco T., Cerny M. 2006. Management of environmental crop conditions to produce useful sunflower oil components. European Journal of Lipid Science and Technology, 108 (4): 287 297 http://dx.doi.org/10.1002/ejlt.200500310

Sarkar D., Mandal B., Kundu M C. 2007. Increasing use efficiency of boron fertilisers by rescheduling the time andmethods of application for crops in India. Plant and Soil, 301: 77-85 http://dx.doi.org/10.1007/s11104-007-9423-1

Sarawgi S. K., Rajput R. S. 2005. Effect of phosphorus, zinc and PSM on growth and yield of soybean in vertisols of Chhattisgarh plain. Annual Agricultural Research, 26 (2): 302-305

Seyed Sharifi R., Khavazi K. 2011. Effects of seed priming with Plant Growth Promoting Rhizobacteria (PGPR) on yield and yield attribute of maize (Zea mays L.) hybrids. Journal of Food, Agriculture and Environment, 9 (3-4): 496-500

Son T. T. N., Diep C. N., Giang T. T. 2006. Effect of Bradyrhizobia and phosphate solubilizing bacteria application on soybean in rotational system in the Mekong Delta. Omonrice, 14: $48-57$

Subedi K. D., Ma B. L. 2009. Assessment of some major yieldlimiting factors on maize production in a humid temperate environment. Field Crops Research, 110: 21-26 http://dx.doi.org/10.1016/j.fcr.2008.06.013
Thenua O. V. S., Kuldeep S., Vivek R., Jasbir S. 2014. Effect of sulphur and zinc application on growth and productivity of soybean [Glycine max. (L.) Merrill] in northern plain zone of India. Annual Agricultural Research, 35 (2): $183-187$

Wu S. C., Cao Z. H., Li Z., Cheung K. C., Wong M. H. 2005. Effects of biofertilizer containing $\mathrm{N}$-fixer, $\mathrm{P}$ and $\mathrm{K}$ solubilizers and AM fungi on maize growth: a greenhouse trial. Geoderma, 125: 155-166 http://dx.doi.org/10.1016/j.geoderma.2004.07.003

WRB. 2014. World reference base for soil resources 2014 . International soil classification system for naming soils and creating legends for soil maps. World Soil Resources Reports No. 106. FAO, Rome

Yin J., Wang A., Wei W., Liu Y., Shi, W. 2005. Analysis of the operation conditions for supercritical fluid extraction of seed oil. Separation and Purification Technology, 43: 163-167 http://dx.doi.org/10.1016/j.seppur.2004.10.016 
ISSN 1392-3196 / e-ISSN 2335-8947

Zemdirbyste-Agriculture, vol. 103, No. 3 (2016), p. 251-258

DOI 10.13080/z-a.2016.103.032

\title{
Biotrąšos ir cinkas didina sojų derlių, gumbelių formavimąsi ir nesočiųjų riebiųjų rūgščių kiekị
}

\author{
R. Seyed Sharifi \\ Mohaghegh Ardabili universiteto Gamtos išteklių ir žemės ūkio kolegija, Iranas
}

\begin{abstract}
Santrauka
Siekiant ištirti biotrąšu ir cinko įtaką sojų derliui, gumbelių formavimuisi ir riebalu rūgščiu sudèčiai, 2013 ir 2014 m. buvo atlikti dviejų veiksnių lauko eksperimentai. Pirmas veiksnys - keturios normos nanocinko oksido: be nanocinko oksido ( $\mathrm{Zn} 0)$ (kontrolinis variantas), 0,3 (Zn1), 0,6 (Zn2) ir 0,9 (Zn3) g L-1, antrasis - penkios normos biotrąšų: be biotrąšų (B0), sẻklų inokuliavimas Bradyrhizobium japonicum (B1), B. japonicum + Azosprillum lipoferum padermé OF (B2), B. japonicum + Pseudomonas putida padermé 186 (B3) ir B. japonicum + A. lipoferum padermé $\mathrm{OF}+P$. putida padermé 186 (B4). Tyrimo rezultatai parode், kad maksimalus gumbeliu viename augale skaičius $(16,55)$ ir grūdų derlius $\left(1875 \mathrm{~kg} \mathrm{ha}^{-1}\right)$ buvo nustatytas Zn3B4 variante. Didžiausias vieno augalo sausasis gumbelių svoris, ankštarų ir grūdų skaičius iš vieno augalo taip pat buvo Zn3B4 variante. Aliejaus ir baltymų kiekis padidejo panaudojus biotrąšas ir nanocinko oksidą. Aliejaus maksimalius kiekis nustatytas variante, kuriame buvo panaudota $0,9 \mathrm{~g} \mathrm{~L}^{-1}$ nanocinko oksido ir B4 inokuliavimas. Sočiųjų riebalų rūgščių (palmitino ir stearino) kiekis sumažèjo inokuliavus biotrąša, palyginus su kontroliniu variantu, o nesočiujjų riebalų rūgščių (linolo, linoleno ir oleino) kiekis padidejjo. Tyrimo rezultatai parodè, kad ir biotrąšų, ir $0,9 \mathrm{~g} \mathrm{~L}^{-1}$ nanocinko oksido (Zn3B4) panaudojimas grūdų derlių padidino apie 68 \%, palyginus su Zn0B0 variantu. Remiantis tyrimų rezultatais padaryta išvada, kad siekiant pelningo sojų auginimo, galima rekomenduoti koinokuliavimą B. japonicum + augalų augimą skatinančiomis bakterijomis ir nanocinko oksido naudojimą.
\end{abstract}

Reikšminiai žodžiai: augalų augimą skatinančios rizobakterijos, aliejaus kiekis, derlius, Glycine max, Rhizobium.

Please use the following format when citing the article:

Seyed Sharifi R. Application of biofertilizers and zinc increases yield, nodulation and unsaturated fatty acids of soybean. Zemdirbyste-Agriculture, 103 (3): 251-258 DOI 10.13080/z-a.2016.103.032 